\title{
Granulocytic sarcoma: misleading immunohistological staining with MT1 and S100 protein antibodies
}

\author{
C J ELLIOTT,* K P McCARTHY, * R L CARTER, ${ }^{*} \dagger$ P DAVIES* \\ From the *Department of Histopathology, and the †Institute of Cancer Research, Royal Marsden Hospital, \\ Surrey
}

SUMMARY Tissue from two patients with granulocytic sarcomas stained positively for MT1 and S100 protein antibodies; both of these cases presented considerable clinical and histological diagnostic difficulties until acute myeloblastic leukaemia spread to the bone marrow. Tissues from a further eight patients with granulocytic sarcoma were also examined retrospectively. Seven of them stained for MT1 and four for S100 protein but the traditional histological markers for myeloid cellschloroacetate esterase and lysosyme - often stained only weakly and focally. This pattern of staining should raise the possibility of a granulocytic sarcoma in otherwise problematic cases.

Granulocytic sarcoma is difficult to diagnose in the absence of spread to the bone marrow of acute myeloblastic leukaemia (AML), ${ }^{1}$ and it may be overlooked in the differential diagnosis of small round cell tumours without evidence of myeloid differentiation. Nieman et al showed that the diagnosis was suspected in only $44 \%$ of patients with granulocytic sarcoma and that $91 \%$ of the remainder were initially misdiagnosed as malignant lymphoma. ${ }^{2}$ The importance of correctly identifying granulocytic sarcoma is emphasised by Mansi et al, who found that patients diagnosed at presentation and treated with the appropriate drug regimens for AML had remissions lasting from two to 16 months; patients initially misdiagnosed as having lymphoma did not have a period of remission. ${ }^{3}$

A vital clue to the diagnosis will be missed if the pale green appearance of the fresh macroscopic tumour passes unremarked or unrecorded, and this will occur if the material is received already fixed. The colour is due to the presence of myeloperoxidase (verdoperoxidase), ${ }^{2}$ a pigment which fades on exposure to air but can be restored by the application of peroxide. ${ }^{4}$ Not all cases are green. ${ }^{5}$ Chloroacetate esterase (CAE) and lysosyme stains have been reported to stain $75 \%$ and $89 \%$ of granulocytic sarcomas, respectively. ${ }^{2}$ Ultrastructural investigations may indicate three distinct types of electron dense granules, ${ }^{5}$ notably ellipsoidal granules which contain axial crystals. ${ }^{6}$ It is now apparent that the diagnostic difficulties posed by granulocytic sarcomas may be compounded still fur-

Accepted for publication 6 October 1988 ther by anomalous staining reactions in certain immunohistological procedures. We have recently encountered strong positivity for MT1 and S100 protein in two patients in whom the diagnosis of granulocytic sarcoma was not made until bone marrow disease as a result of acute myeloblastic leukaemia became apparent. In both cases the marrow was initially normal, and the patients presented with widespread lymph node enlargement (case 1) and retroperitoneal tumour (case 2). These misleading results prompted a review of immunohistochemical staining of granulocytic sarcoma for MT1 and S100 protein in stored tissue blocks from a further eight patients.

\section{Material and methods}

Material fixed in formol-saline and embedded in paraffin wax was batch-stained for lysosyme (Dako), ${ }^{7}$ MT1 (Eurodiagnostics), ${ }^{89}$ MB1 (Eurodiagnostics) ${ }^{89}$ and S100 protein (Dako) ${ }^{10-12}$ using the alkaline-phosphatase antialkaline phosphatase (APAAP) technique, and for chloroacetate esterase. ${ }^{13}$ Lysosyme (muraminidase) stains myeloid cells and histiocytes. MT1 is an antibody directed against restricted CD45 and stains not only mature and immature $\mathrm{T}$ lymphocytes, but also myeloid cells, some macrophages, and some immature B cells. ${ }^{89} \mathrm{MB} 1$ also identifies part of the leucocyte common antigen complex (CD45) and stains all B cells and $50 \%$ of mature (but not immature) $\mathrm{T}$ cells. ${ }^{8}$ Other antibodies directed against restricted CD45, such as MT2, MB2, and UCHL1 may be of use in identifying anomalous staining in granulocytic sarcoma; UCHL1, for instance, is rarely 
Table 1 Staining of granulocytic sarcomas with $C A E$ (chloroacetate esterase) and antibodies to $M T 1, M B 1$, lysosyme and $S 100$ protein

\begin{tabular}{lcllll}
\hline $\begin{array}{l}\text { Case } \\
\text { No }\end{array}$ & $C A E$ & $M T I$ & $M B I$ & S100 & Lysosyme \\
\hline 1 & $(+)$ & + & - & $(+)$ & $(+)$ \\
2 & ++ & ++ & - & ++ & + \\
3 & $(+)$ & ++ & - & - & $(+)$ \\
4 & ++ & ++ & - & $(+)$ & + \\
5 & ++ & - & - & - & $(+)$ \\
6 & ++ & ++ & - & ++ & ++ \\
7 & ++ & ++ & - & + & + \\
8 & ++ & ++ & - & - & - \\
9 & $(+)$ & + & - & $(+)$ & ++ \\
10 & ++ & ++ & - & - & ++ \\
\hline \\
\hline
\end{tabular}

positive (CJ Elliott, personal communication). S100 protein is a calcium binding protein similar in structure to calmodulin ${ }^{10}$ which was originally identified in glial cells but has since been detected in a wide variety of normal and neoplastic tissues, including the central and peripheral nervous systems and related tumours, melanocytes, and melanoma Langerhans' cells" and eosinophilic granuloma and various epithelial and non-epithelial lesions. ${ }^{10}$ A subset of $\mathrm{T}$ suppressor/ cytotoxic lymphocytes has also been shown to stain for S100 protein. ${ }^{12}$

Staining was assessed independently by three pathologists (CE, KM, RLC) and scored as indicated in table 1.

Ten cases of granulocytic sarcoma from seven men and three women, aged 19-60 years (median 31 years), were studied. In seven patients the solid tumour was the presenting feature-two were found to have spread to the bone marrow by AML at presentation, four developed AML after initially normal bone marrow biopsies (two weeks-one year later), and one patient died within a year of presentation without evidence of leukaemic marrow disease. In two patients with chronic granulocytic leukaemia (CGL) granulocytic sarcoma heralded blastic transformation, and one patient who had received a bone marrow transplant for AML was found to have relapsed following the development of granulocytic sarcoma. Further clinical details are given in table 2 .

\section{Case reports}

CASE 1

A 19 year old man presented with a mediastinal mass and generalised lymphadenopathy. A biopsy specimen of an inguinal lymph node showed replacement of normal structures by a tumour composed of medium sized round cells with scanty cytoplasm. Only formalin fixed, paraffin wax embedded material was available for special stains, which, together with the clinical details, suggested a diagnosis of $T$ lymphoblastic lymphoma. One year later after chemotherapy and bone marrow transplantation the patient developed acute myeloblastic leukaemia.

\section{CASE 2}

A 30 year old man presented with a retroperitoneal mass and malaise. The tumour was composed of medium sized cells with small, densely staining nuclei and eosinophilic cytoplasm, and was shown on electron microscopy to contain granules of indeterminate type. The cells were arranged in packets bordered by reticulin and delicate blood vessels. Results from special stains were equivocal, suggesting either a paraganglioma or granulocytic sarcoma. Bone marrow biopsy specimens taken at this time were normal. In the absence of helpful immunohistochemical staining a diagnosis of paraganglioma was favoured on the basis of the clinical picture and the growth pattern of the tumour. Two weeks later a nuclear magnetic resonance scan showed diffuse marrow abnormalities and a repeat bone marrow aspirate showed acute myeloblastic leukaemia.

Table 2 Patient details

\begin{tabular}{|c|c|c|c|c|c|c|}
\hline Case & Age & $\operatorname{Sex}$ & Site & $\begin{array}{l}\text { Leukaemia } \\
\text { at presentation }\end{array}$ & Initial diagnosis & Subsequent course \\
\hline 1 & 19 & $\mathbf{M}$ & Inguinal lymph node & No & T lymphoblastic & AML 1 year after presentation \\
\hline $\begin{array}{l}2 \\
3 \\
4\end{array}$ & $\begin{array}{l}30 \\
45 \\
32\end{array}$ & $\begin{array}{l}\mathbf{M} \\
\mathbf{M} \\
\mathbf{F}\end{array}$ & $\begin{array}{l}\text { Retroperitoneum } \\
\text { Hickman line insertion } \\
\text { Breast }\end{array}$ & $\begin{array}{l}\text { No } \\
\text { CGL for one } 1 \text { year } \\
4 \text { months after bone } \\
\text { marrow } \\
\text { transplantation for } \\
\text { AML }\end{array}$ & $\begin{array}{l}\text { Paraganglioma } \\
\text { Granulocytic sarcoma } \\
\text { Granulocytic sarcoma }\end{array}$ & $\begin{array}{l}\text { AML } 2 \text { weeks later } \\
\text { AML } 4 \text { weeks later } \\
\text { AML relapse at time of biopsy }\end{array}$ \\
\hline $\begin{array}{l}5 \\
6 \\
7 \\
8\end{array}$ & $\begin{array}{l}39 \\
26 \\
53 \\
36\end{array}$ & $\begin{array}{l}\mathbf{M} \\
\mathbf{M} \\
\mathbf{M} \\
\mathbf{M}\end{array}$ & $\begin{array}{l}\text { Rib } \\
\text { Small intestine } \\
\text { Upper arm } \\
\text { Supraclavicular lymph } \\
\text { node }\end{array}$ & $\begin{array}{l}\text { No } \\
\text { No } \\
\text { No } \\
\text { No }\end{array}$ & $\begin{array}{l}\text { Undifferentiated sarcoma } \\
\text { Lymphoblastic lymphoma } \\
\text { Granulocytic sarcoma } \\
\text { Granulocytic sarcoma }\end{array}$ & $\begin{array}{l}\text { AML in marrow at time of biopsy } \\
\text { AML } 2 \text { weeks later } \\
\text { No AML, died } 1 \text { year later } \\
\text { AML in marrow at time of biopsy }\end{array}$ \\
\hline $\begin{array}{r}9 \\
10\end{array}$ & $\begin{array}{l}60 \\
25\end{array}$ & $\begin{array}{l}\mathbf{F} \\
\mathbf{F}\end{array}$ & $\begin{array}{l}\text { Cervical lymph node } \\
\text { Small intestine }\end{array}$ & $\begin{array}{l}\text { CGL for } 6 \text { years } \\
\text { No }\end{array}$ & $\begin{array}{l}\text { Granulocytic sarcoma } \\
\text { Lymphoblastic lymphoma }\end{array}$ & $\begin{array}{l}\text { AML in marrow at time of biopsy } \\
\text { AML } 2 \text { weeks later }\end{array}$ \\
\hline
\end{tabular}


Results

Table 1. All cases showed chloroacetate esterase staining, although in three this was very weak and focal. Tumours from nine of the 10 patients showed lysosyme positivity, again weak and focal in three. Nine of 10 tumours exhibited MT1 positivity, which was often extensive and strong. No tumours were positive for MB1. Six stained for S100 protein-three strongly and three very weakly.

\section{Discussion}

Several points emerge from this study. The diagnosis of granulocytic sarcoma should be borne in mind when investigating undifferentiated tumours in patients presenting with an unusual clinical history. A useful clue to the diagnosis may be missed if the pale green colour of the macroscopic specimen is absent or not noted. Chloroacetate esterase and lysosyme staining may be very weak and focal in primitive examples of granulocytic sarcoma, while other stains, such as MT1 and S100 protein antibodies, may be widely positive. Neither the clinical, histological, nor immunohistological pictures can be used in isolation; all evidence must be considered together when reaching a diagnosis. Ultrastructural studies may contribute if electron dense granules are shown within the tumour. Soft tissue manifestations of acute myeloid leukaemia sometimes precede marrow disease by several weeks or months, and some patients never develop the typical leukaemic picture.

The finding of strong MT1 staining in nine of 10 granulocytic sarcomas in our series is not surprising as, in addition to mature and immature $T$ and immature B lymphocytes, myeloid cells stain positively with this antibody. ${ }^{89}$ Interestingly, the degree and extent of tumour staining with MT1 may exceed that for CAE and lysosyme. MT1 identifies part of the leucocyte common antigen complex and might be expected to be present on very primitive myeloid cells; chloroacetate esterase and lysosyme are generally produced by more mature myeloid precursors. The inclusion of other T cell markers, such as UCHLl in an antibody panel may assist the identification of anomalous MT1 positivity. Some tumours expressing both MT1 and CAE may be derived from pluripotential cells, and Childs $e t$ al have described coexpression of several markers of $\mathrm{T}$ lymphocytes and myeloid cells in one tumour. ${ }^{14}$ Several other reports of lymphoblastic lymphoma preceding myeloblastic leukaemia are cited by these authors in support of this finding. ${ }^{1516}$

The demonstration of positive staining for $\mathrm{S} 100$ protein (albeit often weak and focal) in six of 10 granulocytic sarcomas is difficult to explain as this protein is usually associated with cells and tumours of neuroectodermal origin. Marrow-derived elements such as Langerhan's cells ${ }^{11}$ and some T lymphocytes ${ }^{12}$ have, however, been reported to stain for $\mathrm{S} 100$ protein.
In conclusion, we emphasise the need for caution in interpreting unexpected immunohistological staining in undifferentiated small cell tumours. The diagnosis of granulocytic sarcoma should be considered, even in the absence of concurrent marrow disease as a result of acute myeloid leukaemia, and lysosyme or chloroacetate esterase positivity, however weak, should not be ignored.

We thank Drs C Corbishley and G Farrer-Brown for supplying the tissues for cases 8 and 9 and Liz Philp and Jane Taylor for technical assistance.

\section{References}

1 Krause JR. Granulocytic sarcoma preceding acute leukaemia: a report of six cases. Cancer 1979;44:1017-21.

2 Neiman RS, Barcos M, Berard C, et al. Granulocytic sarcoma: a clinicopathologic study of 61 biopsied cases. Cancer 1981; 48:1426-37.

3 Mansi JL, Selby PJ, Carter RL, Powles RL, McElwain TJ. Granulocytic sarcoma: a diagnosis to be considered in unusual lymphoma syndromes. Postgrad Med J 1987;63:447-9.

4 Sears HF, Reid J. Granulocytic sarcoma: local presentation of a systemic disease. Cancer 1976;37:1808-13.

5 Scott RE, Horn RG. Ultrastructural aspects of neutrophil granulocyte development in humans. Lab Invest 1970;23:202-15.

6 McCarty KS, Wortman J, Daly J, Rundles RW, Hanker JS. Chloroma (granulocytic sarcoma) without evidence of leukemia: facilitated light microscopic diagnosis. Blood 1980; 56:104-8.

7 Meister P, Huhn D, Nathrath W. Malignant histiocytosis. Immunohistochemical localisation on paraffin-embedded sections. Virchows Arch (Pathol Anat) 1980;385:233-46.

8 Poppema S, Hollema H, Visser L, Vos H. Monoclonal antibodies (MT1, MT2, MB1, MB2, MB3) reactive with leucocyte subsets in paraffin embedded tissue sections. Am J Pathol 1987;127: 418-29.

9 Dobson CM, Myskow MW, Krajewski AS, Carpenter FH, Horne CW. Immunohistochemical staining of non-Hodgkin's lymphoma in paraffin sections using the MB1 and MT1 monoclonal antibodies. J Pathol 1987;153:203-12.

10 Nakajima T, Kameya T, Watanabe S, Hirota T, Sato Y, Shimosato Y. An immunoperoxidase study of S-100 protein distribution in normal and neoplastic tissues. Am J Surg Pathol 1982;6:715-27.

11 Cocchia D, Michetti F, Donata R. Immunochemical and immunocytochemical localisation of S-100 antigen in normal human skin. Nature 1981;294:85-7.

12 Takahashi K, Isobe T, Ohtsuki Y, Sonobe H, Yamaguchi H, Akagi T. S-100 protein positive human T-lymphocyte. Am $J$ Clin Pathol 1985;83:69-72.

13 Moloney WC, McPherson K, Fliegelman L. Esterase activity in leucocytes demonstrated by the use of napthol-AS-Dchloroacetate substrate. J Histochem Cytochem 1960;8:200-7.

14 Childs CC, Chrystal GS, Strauchen JA. Biphenotypic lymphoblastic lymphoma: an unusual tumour with lymphocytic and granulocytic differentation. Cancer 1986;57:1019-23.

15 Posner MR, Said J, Pinkus G, et al. T-cell lymphoblastic lymphoma with subsequent acute non-lymphocytic leukaemia -a case report. Cancer 1982;50:118-24.

16 Kjeldsberg CR, Nathwani BN, Rappaport H. Acute myeloblastic leukaemia developing in patients with mediastinal lymphoblastic lymphoma. Cancer 1979;44:2316-23.

Requests for reprints to: Dr K P McCarthy, Department of Histopathology, Royal Marsden Hospital, Downs Road, Sutton, Surrey SM2 5PT, England. 